\title{
Surviving a Cultural Genocide: Perspectives of Indigenous Elders on the Transfer of Traditional Values
}

\author{
Shawn Clark ${ }^{1}$ \\ University of Providence, USA \\ Ruth Wylie \\ Arizona State University, USA
}

\begin{abstract}
The purpose of this ethnographic study was to examine how Indigenous elders perceive traditional values. This study employed Portraiture, which allowed Indigenous elders to share their stories in a culturally tailored and relational manner. The authors' captured and present richly detailed stories that describe the intersects between human experiences and sacred beliefs. The scholars eloquently braid the first authors experiences at three (3) traditional Indigenous ceremonies with the words of Indigenous elders to tell a story about overcoming an attempted cultural genocide. The ceremony participation and elder visits helped identify ten traditional values encasing spirituality displayed in the Hoop of Traditional Blackfoot Values presented in the English language and the Blackfoot language.
\end{abstract}

Keywords: Blackfoot, elders, indigenous methodologies, native Americans, portraiture.

"When we talk about genocide the definition is to extinguish the culture through the children." Indigenous Elder

\section{How Do Indigenous Elders Perceive Traditional Values?}

In the story that follows, we paint a portrait of a cultural journey to explore the unexplored - to ingest, feel, discover, and be inspired by the traditional Indigenous values that triumphed over an attempted cultural genocide. We aimed to capture richly detailed stories that describe the intersects between human experiences and sacred beliefs - to map out goodnessseize the intricacy and nuances that encourage the being to listen for a story (Lawrence-Lightfoot \& Davis, 1997).

Listening for a story is different from listening to a story-one is passive and reliant on the storyteller, the other is active, and creates an empathetic experience between the two that allows the storyteller to share and the listener to discover hidden passages of words and thoughts. This type of discourse has underpinnings related to a kind of exchange described by Carbaugh (1999) used during his study with Indigenous people to discover the secrecy of harmony among the physical and the spiritual worlds. We borrow from these concepts and offer a unique form of portraiture we call cultural listening.

Cultural listening refers to a type of discourse that connects the storyteller and the listener through an empathetic exchange. The word empathy means 'the action of understanding, being aware of, being sensitive to, and vicariously experiencing the feelings, thoughts, and experience of

${ }^{1}$ Corresponding Author E-Mail: shelbycoyotes@ gmail.com 
another of either the past or present without having the feelings, thoughts, and experiences fully communicated in an objectively explicit manner' (Merriam-Webster.com Dictionary, 2021). Cultural listening is dependent on the listener having precise knowledge of the worldview being explored and using empathy to discover nuances in the way the speaker uses words, changes tone, and has the slightest inflection to transport the listener into the experiences of the speaker to find stories neatly tucked within the original story. As part of cultural listening, empathy doesn't require the listener to absorb the storyteller's feelings. Instead, it requires the listener to appreciate how the storyteller's worldview impacts their feelings, thoughts and experiences.

We learned during our study that Indigenous elders rarely discuss sacred or holy knowledge directly; instead, they use stories that surround the sacred knowledge, leaving the task of discovery to the listener. ${ }^{2}$ The term elder is generally associated with an older Indigenous individual who is believed a keeper of sacred knowledge and possess cultural insights germane to sustaining traditional culture (Pepion, 1999). To demonstrate the attributes of cultural listening and how we used the process during our study to seize knowledge, we attach a portion of an elder visit captured by the first author:

There was an elderly gentleman and every time I would go to him to have my face painted, he would say, what's your name? And I would tell him, and he would paint my face. After I got to know him on a regular basis, he would still ask me my name. I remember thinking why he is asking my name-he knows my name. I thought it was a human to human thing, but as I learned more about our way of culture and engagement in spiritual connection, I came to understand that what he was saying was-what is your name? and he was acting on behalf of the Creator. So, when he would say what is your name? And I would tell him my name ... the Creator would recognize me distinctly as me.

In the above excerpt, the listener can comprehend the elder explaining her discovery of the sanctity of her Indian name and in many scholarly endeavors that would have sufficed the intent of the study. However, what I heard in the exchange was a pathway to discovering a much deeper understanding of how Indigenous people connect to their spirituality that led to eliciting deeper insights into Indigenous spirituality. In follow-up discussions, elders offered the following conclusions:

I think your Indian name is your spirit ... If people are calling me by my Blackfoot name it has meaning — it has feeling — and has a spirit with it.

In our story, we used cultural listening to learn how Blackfoot elders perceive traditional values-Attending and participating in traditional Blackfoot ceremonies was essential to our discoveries. The Blackfoot believe cultural traditions and spiritual practices are chronicled in stories that explain their origin (Hernandez, 1999) and are transferred through oral traditions embedded in ceremonies that are reenactments of the origin and creation stories retold the same way they were told centuries ago (Bastien, 2004; Pepion, 1999). The Blackfoot Confederacy is an

\footnotetext{
${ }^{2}$ For the current article, the terms American Indian, Native American (Lowe \& Struthers, 2001), Native (Hill, 2006), and Indigenous were used interchangeably throughout this article, "relating to people who trace their ancestral origins to the indigenous cultures and peoples of the Americas" (Strayhorn, 2016, p. 67). The term American Indian commonly denotes tribes residing in the United States that have received federal recognition (Struthers et al., 2005; Hill, 2006).
} 
alliance between the Amskapi Piikani, located in Montana, the Apatohsi Piikani located in southern Canada, the Siksika Blackfoot (Northern Blackfoot) situated in Canada, and the Kainai (Blood) also found in Canada (Crowshoe \& Manneschmidt, 2002; Gladstone \& Pepion, 2016; Pepion, 1999). ${ }^{3}$

\section{Cultural Journey}

In the narration that follows, we offer poignant stories, so the reader has a context to draw connections between our visits with Indigenous elders and our experiences at traditional ceremonies that highlight our findings. We, at times, use both the English language and the Blackfoot language, the Native language of the Tribal Nations included in this study. Blackfoot language in written form has only been around for about a century and has been reinvented several times by educators, linguists, and missionaries (Miyashita \& Chatsis, 2013). The names of the ceremonies are presented in traditional Blackfoot language, in the order of attendance, and include: 1) Poi - sski - năkk - ssin Ceremony, 2) Ninamska Paskan Ceremony, and 3) Akokatsin Ceremony.

\section{Poi - sski - năkk - ssin Ceremony}

We began this study with the first author building reciprocal relationships by participating in a traditional face painting ceremony at his elder liaison's home. Blackfoot scholars maintain that Blackfoot warriors used face paint when they went into battle to look good for their Creator if they perished (Long Standing Bear Chief, 1992). Another scholar indicated that the Blackfoot commonly use face painting during ceremonies (Wissler, 1912). My elder liaison said, "in modern times, face painting is done to receive a blessing and show you are learning with us." The elder liaison is an enrolled Tribal member, employee of the Tribal nation, a ceremonial bundle holder, and participates in traditional ceremonies. He is guided spiritually and culturally by holy grandparents who performed the face painting ceremony. The holy grandparents were an integral part of navigating the first author through his cultural journey.

\section{Poi - sski - năkk - ssin Journey}

The drive from my home to the Blackfeet nation is less than an hour-I had made the drive hundreds of times throughout my lifetime and knew the road like the back of my hand. I drove down a nearly straight and narrow two-lane road that was barely wide enough to fit two vehicles on - the road is like a rollercoaster-rising and falling with the changing landscape. I gazed into the distance at the snow-peaked mountains that seemed to be born from the wind sweep prairie; the mountain tops were colliding with an endless Big Sky. The stiff gusts of wind leaked into my vehicle as an entangled ball of sagebrush crashed into my windshield and continued on its journey to some unknown destination.

\footnotetext{
${ }^{3}$ The Blackfoot people are called the Nitsitapiksi or Niitsitapi, which means Real People and individuals that can speak the Real Language are called Nitsipoiyiksi (Bastien, 2004). "The general term "Blackfoot" refers to all the Confederated tribes as a whole, whereas the term "Blackfeet" reference an individual within the Confederacy or the tribe of the Confederacy whose lands reside under the dominion of the United States of America" (Hall, 2018, p. 5). The difference in spelling between Pikani and Piikani represents a lack of agreement to standardized spelling between the Blackfoot Confederacy members (Gladstone \& Pepion, 2016).
} 
I drove through the largest community boarding the Blackfeet nation, crossed over the Cut Bank Creek, and gave a glance at a dilapidated road sign indicating that I was now on the Blackfeet Indian reservation - it would be the only acknowledgment that I was now in another country. The Blackfeet Indian reservation encompasses nearly 1.5 million acres and rests against the Rocky Mountain to the west and Alberta, Canada to the North (Pepion, 2013).

My elder liaison has a modest home situated near the center of the largest community located on the reservation. I walked through the front door and noticed his holy grandparents were seated in beach chairs at the western end of a narrow living room. Positioned in front of each of them was a neatly folded, brightly colored Pendleton blanket - there were also several other brightly colored blankets stretched across the back of a couch and a chair. I learned from my elder liaison that Native Americans often gift Pendleton blankets as a sign of respect.

The blankets are symbolic of our relationship with the fur traders-they would give us the blankets as gifts ... we have continued to give them as gifts but it's more a sign of respect for doing a worthy deed like serving in the military or a sign of generosity for doing something to help us personally or to better our people.

The gifting of blankets has a long and notorious history with Native Americans. Scholars suggested that blankets purposely infected with smallpox were given to Native Americans to annihilate them (Deloria, 1970). One scholar Indicated that blankets infected with smallpox were distributed to Indigenous people (Houston \& Houston, 2000), and another scholar suggested the British were ordered to engage in biological warfare against Native Americans, stating, "Infect the Indians with sheets upon which smallpox patients have been laying, or by any other means which may exterminate this accursed race" (Mayor, 1995, p. 58).

I watched the holy grandfather place a small wooden box called an altar between him and the holy grandmother and lite a small amount of sweetgrass. They both fanned the smoke, called smudging, into their faces and through their hair as the holy grandfather said a prayer in his Indigenous language.

The interconnectivity between smudging and spirituality was underscored by elders and observed by the first author at ceremonies. Bassett, Tsosie, \& Nammauck (2012) defined smudging as "a purification practice that involves burning a bundle of dried herbs such as sage" (p. 19). Portmann \& Garrett (2006) suggested that "The smoke is considered a very powerful cleansing spirit and is used to purify people, ceremonial grounds, homes, and sacred objects, or to send messages to a greater spirit" (p. 464). A Blackfoot scholar maintained that smudge is used to cleanse and represents prayers being transferred to the Creator (Pepion, 1999). Scholarly literature indicated that smudging was believed to protect children from perilous situations (Zedeño, 2008). Elders said that smudging connects you to your spirit world - to the ancestors that have passed and sacred knowledge:

When you're praying-when you light your smudge, you're waking everybody up in the upper world-the spirit world-they're called to attention to help you-to support you ... We smudge to connect to our Creator ... In ceremony, when we make that smudge all of the doors are open ... The smoke goes through us to our Creator ... Smudging connects us to Natoosii ... We smudge when we are going to connect with the spirit world... When you're struggling you go see an elder-pray and light your 
smudge and it will take your prayers up. Even if you've never smelt sweetgrass it creates a calmness in you.

I learned from the holy grandfather that when Indigenous people lived in tipis they would smudge (ăwăamătō'osimăa) by placing a small wooden box called an altar

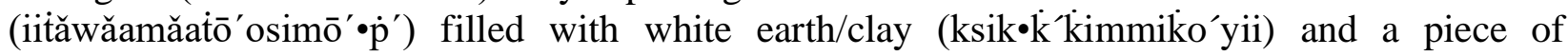
"sweetgrass (Sevastana odorata), sweet pine (Abies lasiocarpa), narrow leaved puccoon (Lithospermum linearifolium) or wild parsnip (Leptotaenia multifida)" (Wissler, 1912, p. 255) that would then be placed on the west side $\left(\mathrm{yo}^{\prime} \bullet \dot{p}^{\prime}\right)$ of the tipi. Sweetgrass is entwined with Indigenous culture and is often used as a ceremonial smudge (Shebitz \& Kimmerer, 2004). Indigenous author Robin Wall Kimmerer (2013) described sweetgrass as "the hair of Mother Earth, is traditionally braided to show loving care for her well-being. Braids plaited of three strands, are given away as signs of kindness and gratitude" (p.197).

I approached the holy grandfather, kneeled on the Pendleton blanket, and placed an offering of \$20.00 and two bags of pouch tobacco in a wicker basket. The holy grandfather used red brick paint to put a dot on my forehead, then my cheek, next to my chin, and then my other cheek. He then used both hands to spread the paint while he said a prayer in his Indigenous language.

The Blackfoot believe that paint is a vital intermediary between people and the spirit world; it is related to all things, from warding off evil spirits and odious dreams to capturing the most beneficial influencers in the cosmos (Zedeño, 2017). Paint is believed to possess the authority to regenerate or provide static objects, transform something or life into something else, and cure the physical person and the spirit (Zedeño, 2017). I learned that you need to have been transferred special rights to possess sacred paint or to paint another person during a ceremony:

\section{Not just anyone can acquire our paint and use it in a ceremony. Only those who have been granted the authority through transfer or from the spirits of their ancestors can gather paint from our sacred sites and use it in our ceremonies.}

I moved to a nearby sofa, eager to watch and listen for a story embedded with sacred wisdom. One by one, I watch parents and grandparents with their young children and grandchildren enter the house, discuss proper protocol, walk up to one of the holy grandparents, knell down on the blanket, make their offering, and get their face painted. Most stayed for a while, sharing stories and expressing gratitude towards the elders. Some expressed emotion-jovial—-tears-laughterothers sat in silence, listening for sacred wisdom.

\section{Ninamska Paskan Ceremony}

The Ninamska Paskan Ceremony was the ceremonial bundle opening for the first author's elder liaison. The ceremony is held following the first sound of thunder. The ceremony had initially been scheduled outside in tipis, but an early summer rainstorm forced the event inside the local community college.

Scholars noted that Native American Plains tribes have reestablished a bundle system to capture traditional knowledge (Zedeño, 2008) deemed critical for maintaining an Indigenous identity (Bastien 2004; Crowshoe \& Manneschmidt, 2002; Hernandez, 1999). We learned from an elder that the bundle system had a troubled past because of pandemics like smallpox and the influence of Christianity: 
We were at a point where we were being affected by Christianity so people were scared to come forward ... to take these bundles ... there had been a lot of sickness and deaths from the pandemics like smallpox so people lost faith in the bundles... Some of them made fires and threw them in there so we lost some of those bundles and we lost a lot of knowledge that way.

Ceremonial elders believe that bundles live and exist to protect and guide the tribe (Zedeño, 2008). During my visits with elders, I learned that bundles are usually wrapped in animal leather but traditionally were wrapped in some cloth-like silk (Wissler, 1912) and contain artifacts such as animal parts, rocks, pipes, and other components of nature (Lokensgard, 2001). Our study's elders mentioned that all of the objects in a bundle are interrelated and create their power.

\section{Ninamska Paskan Journey}

I positioned myself behind the seating area towards the back of the room between two women who wore brightly colored shawls and matching scarfs covering their hair. I learned from one of the women that her shawl had been passed to her by her grandmother, and the color signifies her society affiliation. Blackfoot scholars maintained that shawls are sacred and are passed between generations of women stating,

Shawls are sacred attire worn during ceremony ... Elders teach us that the shawl represents a woman's unique story ... Shawls and shawl designs are passed between the generations from mothers to daughters or grandmothers to granddaughters (Jackson et al., 2015, p. 11).

Women were charged with numerous facets of traditional Blackfoot family life (Taylor, 2012; Wissler, 1912) and played an essential role in preserving and transferring Blackfoot history as oral storytellers. Educating Blackfoot children about family history was the responsibility commonly reserved for women. Like many Indigenous societies, Blackfoot societies were often connected by matrilineal threads resulting in bestowing on grandmothers and other elder women of the tribe being responsible for early education (Portman, 2001). One scholar maintained that Blackfoot women help their children develop their self-identity and shape their worldview by sharing family stories and transferring sacred knowledge tied to ceremonies and traditions (Eli, 2013).

I noted countless other women adorned with colorful shawls and scarfs covering their hair, helping cook hamburgers and hotdogs, making berry soup, and preparing gift bags filled with all kinds of food items - many had children dressed in brightly colored traditional clothing helping with ceremonial activities. Bundle holders are required to have an extensive support system who pledge to help with caring for the bundle and planning the start of the ceremonies, for instance, helping with the sweat lodge for cleansing before the ceremony is performed, collecting necessary resources, carrying out some stages of the ceremony, and preparing the bundle opening meal (Zedeño, 2008).

Situated in front of our standing area was a group of male and female society members arranged in a circle around a small fire built inside a metal container. The men society members sat on the right, and the women society members sat on the left. A group of male drummers and singers sat directly in front of the female society members facing the fire. The holy grandparents sat at the western end of the circle and were separated by a space reserved for the bundle. The male 
singers began singing traditional songs and lightly tapping on their drum as my elder liaison and spouse escorted the bundle through the front doors and down the center aisle, much like a wedding - they positioned themselves at one end of the circle next to their holy grandparents and began praying. We have attached, as Appendix A, a picture of Gladstone and Pepion's ceremonial circle (2016).

The men seated in the circle took turns smoking a pipe filled with tobacco while the whole group sang songs in their Indigenous language. Scholars noted that many Native American tribes use tobacco during traditional ceremonies (Harjo, Burhansstipanov \& Lindstrom, 2014). I learned from one of the elders that the pipe is sacred, and the smoke we see travels to their Creator. Two Bears (cited in Carbaugh, 1999) explained that the pipes used in Blackfeet [Blackfoot] ceremonies are "Made of stone ... The stone represents the earth ... the stem is made of wood ... The wood represents all living things ... The smoke of the pipe is like a spirit ... You see it briefly, then it disappears, up to the Creator" (p. 254).

Indigenous cultures frame spirituality as a way of being and define it as "the belief in the fundamental interconnectedness of all-natural things" (Micmac \& Maliseet Nation News, 1992, p. 30). Elders associate their willingness to persevere with having a deep understanding and appreciation for their spirituality:

We have a responsibility to treat each other with kindness and respect and to be thankful for the Creator giving the Blackfoot people courage to persevere ... Our survival comes from our spirituality ... Although people think we are on this human experience it seems to me that our culture is really a spiritual connection to our Creator ...

Native American spirituality revolves around the necessity of seeking harmony individually, with the broader community, and in relationship with one's environment. During a visit with an elder, I learned that the connections between the spiritual world and the physical world are essential to acquiring harmony and balance. Elders used a metaphor of a wheel to describe harmony and balance:

You can see the wheel start in motion-spiritual-mental-physicalemotional. If one of those little pieces ... aren't working ... the wheel doesn't turn very well.

The metaphor of a wheel ties to a Native American holistic (Meyer, 2009; Archibald, 2008; Cook-Lynn, 2006) worldview lived through a circular manner (Struthers, 2000). The wheel is symbolic of a circle that serves as a reminder of the sacred relationship shared with all of the creations living in this world, and of our responsibility as an aide and donor to the stream of the Circle of Life by existing in harmony and balance with all family members. The circle is represented throughout all parts of life and is a crucial aspect of Indigenous spirituality, family structure, gatherings, and traditional songs and dances (Pewewardy, 1994). The circle is represented by a medicine wheel and used by Indigenous people as a relational and interconnected guidepost for developing successful healing approaches (Absolon, 1993; Absolon, 2010). The medicine wheel encompasses the four directions - east, north, west, and south and the four aspects of life-mental, emotional, physical, and spiritual (Hill, 2006; Dapice, 2006) and contains a historical, social, political, and economic element (Absolon, 2010). 
During the ceremony, I noticed that one of the men inside the circle was responsible for assuring the pipe was filled with tobacco and for managing the fire- - he scurried in and out of the ceremony gathering pieces of wood. I learned from my elder liaison that he is part of the Brave Dog society and is called the pipe-man, and is the only person allowed to move around once the ceremony begins. Blackfoot scholars identified this person as the tobacco cutter or fire keeper and acknowledge he has the responsibility of managing the protocols attached to the ceremony (Gladstone \& Pepion, 2016). A second male, also a member of the Brave Dog society, helped elders find seats near the front of the ceremony near the circle. Traditionally, Brave Dog members were trusted with keeping order while the tribe moved locations and at encampments (Pepion, 1999).

As the pipe was passed, I observed a portion of the bundle was opened until all of the objects were exposed. Once the ceremonial bundle had been fully opened, female helpers began ladling berry soup into cups for all of the ceremony participants and attendees-berry soup is served cold, has a deep purple color, a thick texture, and produces a pungently sweet smell. Wissler (1912) maintained that each person picks a single berry out of their berry soup before eating the soup and prayed to it. I reached into my Styrofoam cup, pulled out a single berry, and held it up as an elder led a prayer

\section{Akokatsin Ceremony}

The Akokatsin ceremony occurs in the outskirts of Standoff, Alberta, Canada. Standoff is situated within the Blood reserve boundaries, is about 30-miles from the U.S. and Canadian international border and is flanked by the Rocky Mountains to the west and wide-open prairies to the east and north. Standoff is a simple village that houses the administrative office of the Blood tribe. The ceremony is held in late summer, lasts 16 and 21 days, and incorporates several different rituals throughout its duration. The first author attended the ceremony on five separate days, usually arriving early in the morning and leaving just before dark.

\section{Akokatsin Journey}

The drive to Standoff would only take about an hour or so depending on the Border crossing it seems to be much easier getting into Canada than it does getting back into my home country of America. During my drive, I would go in and out of four different countries - the Unites States of America, Canada, the Blackfeet nation, and the Blood nation. The Blackfeet and Blood, or as they were called the Peigans, were once a single tribe but were split when the international border was established (Gladstone \& Pepion, 2016).

Place is significant to cultural practice because the landscape holds cultural memories, ancestral histories, and sacred knowledge (Craig, Yung, \& Borrie, 2012). Researchers noted that landscapes are emblematic environments that mirror our culturally centered identity (Greider \& Garkovich, 1994). Scholarly literature indicated that a person's bond impacts individual and group identity development to a geographical area (Basso, 1996). I discovered during my visits with elders that traditional culture is embedded in the land and the stories that help teach sacred lessons:

Culture starts with the landscape-It starts with the territory. The stories that are part of the land. It's just not visiting the sacred places but it's knowing the stories-it creates a sense of belonging. It's just not a geographic boundary but it's where life lessons are demonstrated. 
The Blackfoot Confederacy's traditional homelands extended from the source of the Missouri River (Jackson, 2000) near modern-day Three Forks, Montana, north to the Saskatchewan River in modern-day Canada (Grinnell, 1892; Gladstone \& Pepion, 2016). The land base of the Confederacy has shrunk significantly through treaties and other acts of colonization. The current homeland stretches from East Glacier Park, Montana, to southern Alberta. Elders reminded us about the importance of being in their original land and their connection to sacred landmarks:

The land base is shrinking terribly and has since the 1600's began to shrink but we can say we are unique in that aspect that we are in our original land we can see the landmarks. We can see Chief Mountain-We can see the Sweetgrass Hills—We know where the Sand Hills are located.

With the ending of the Indian Wars, the U.S. government turned its attention towards assimilating American Indians through land allotments. Allotment became the foundation of the U.S. government's Indian policy when the Dawes Act became law in 1887 (Dippel \& Frye, 2020). Allotment intended to open reservation lands up to private ownership (Akee, 2020). Native Americans were traditionally nomadic hunters and struggled to understand the concept of private land ownership (Satterlee, 2002). By the time the Dawes Act had become law, American Indians had already been stripped of nearly $90 \%$ of their traditional lands. By the time the Dawes Act ended, American Indians had lost almost 90 million additional acres of land (Bobroff, 2001).

The history of colonization and the oppression that became part of the Norman Yoke (Brayboy, 2005; Brayboy, 2013) and Manifest Destiny (Calderon, 2014; Pratto \& Stewart, 2011; Sidanius \& Pratto, 1999) continues to plague American Indian society. I learned from elders that, in part, they have been able to survive because they focus on a 'we' mentality instead of an 'I' mentality to outmaneuver the influence of Europeans flocking to the Americas and subscribing to the harmful tenets associated with the settler ideas:

Native American people lived in harmony with nature but when European settlers came it caused turmoil and now, we're the product of that turmoil and now we need to overcome that and get back to our roots-we have to learn those values again if we are going to survive by teaching our kids to survive... When you look at a sense of belonging you need to get rid of that 'I' attitude. Indian people took care of themselves as a 'we' group while the white majority coming into American was about Manifest Destiny-I got to make myself the biggest or most powerful. When you buy into a program it becomes more of a 'we' attitude instead of an 'I' attitude because when you get all of those people in a ceremony it's now a 'we.'

The Blackfoot were no different than other tribes across America who lost their land through treaties or by federal government policies designed to erode their ability to care for their tribal members. The Blackfoot were nomadic hunters who roamed vast territories following the buffalo herds (Lee, 2002) and depended mainly upon the buffalo as their primary economic survival source (Ewers, 1958; Grinnell,1962; McClintock, 1968; Wissler, 1912). Scholars maintained that Indigenous peoples living on the plains never recovered culturally or economically from buffalo loss (Regular, 2009). I learned from elders that their traditional cultural values regarding land ownership differed from the federal government: 
We don't own the land we just use it. It becomes a big task and responsibility to take care of the physical part of the land ... It is not that we didn't believe in property ownership, but to us the land was never viewed as property to be owned by an individual. We used the land to survive as a group ... to follow the bison herds ... when we lost our land, we lost our culture with it.

Scholars noted that nearly all known buffalo jumps are situated in the traditional Blackfoot territory in the Rocky Mountains near present-day Alberta, Montana, and Wyoming and extend to the adjoining prairies (Barsh \& Marlor, 2003). I discovered from an Indigenous elder that the Blackfoot is the only known group to use buffalo jumps:

The buffalo jump is a big part of our language ... The Blackfoot are the only group that has buffalo jumps... If you go along the eastern slopes of the Rockies there are probably thousands of buffalo jumps and out in the prairies all within Blackfoot territories ... there are a whole bunch of buffalo jumps way down south near Yellowstone in northern Wyoming ... and way up north to Saskatchewan and east to the Manitoba border.

The federal government used trickery, and force to remove Indigenous people from their homelands, contributing to an intergeneration trauma and is explored in the literature as historical trauma or the Soul Wound (Duran \& Duran, 1995; Gone, 2013). Historical trauma is explained as the combined experiences shared by groups of people who encountered intentional subjugation through massacres and other hideous acts of colonization (Gone, 2013) across generations (Brave Heart \& DeBruyn, 1998; Crawford, 2014; Gone, 2013). An elder used a creation story to explain the genesis of the Blackfoot:

It goes back to knowing who you are and where you come from and all of those other people came from us. And we can boldly say that is what the old people told us-that's why we're the Amskapi Pikani. That's why we're what they call the Pikani because we were here and everyone branched off from us and there is an old story that goes with that that says the old man had three sons and he sent them out to these different areas-one went north, one went east and one went south. When they came back, they each had their stories and that's how the Piegan, Siksika and Kainai came about.

After crossing the Border, I drove through Cardston, Alberta, and then into Standoff. In the distance, I could see tipis stretching for as far as the eye could see. McClintock (1999) called these Blackfoot encampments White Cities. Zedeño (2017) artfully described a White City, "their hundreds of hide and canvas lodges huddled together, gleaming in the sun of the immense Northwest Plains" (p. 631). I turned onto a gravel road, traveled for few miles, and then turned into the ceremony grounds.

The ceremonial grounds were carved out of a massive field covered in field grass - the Rocky Mountains stood prominently in the distance. The encampment contained hundreds of tipis set in a circle on the outer edge of the grounds. The inner part of the field was left open - many of the tipis were all white, and others were brightly painted. A rudimentary dirt road with deep ruts 
surrounded the entire encampment. As I drove slowly around the grounds searching for my elder liaison, I noticed to my left several sky-blue porta-potties positioned a distance from the tipis- to my right, I noticed makeshift corrals housing young and old horses. I observed children of all ages darting between tipis and running across the road playing.

Blackfoot scholars indicated that traditional learning starts with parents teaching their infants before being shifted to grandparents (Pepion, 1999; Bastien, 2004), where their histories, cultures, and traditional knowledge are transferred (Hall, 2018; Bastien, 2004; Pepion, 1999) through ceremonies, and traditional storytelling (Juneau, 2001). An elder shared their childhood memories about attending ceremonies and how those experiences influence their philosophy about children attending today:

Children learn about the traditional values of respect and responsibility that are part of understanding and following protocols experienced during ceremonies... When you go to ceremony you see that there is a certain way to do things. You notice there is a main teepee, and an outside area where you begin to learn, and as you gain more knowledge you move forward and gain more responsibility ... The more ceremonies you go to the more you see there is an order of respect-respect is a good word-I like to use the word responsibility. When you go to ceremony you see people helping each other-you see the respect for us as a people.

I parked directly behind the tipis of my elder liaison and his holy grandparents. As I began to exit my vehicle, I was met by the elder liaison's 9-old son, who greeted me with excitement. He led me to his camp, where I noticed they had established a makeshift outdoor kitchen. Resting on an old Coleman stove was a well-used coffee pot with dark char marks stretching from its base to the lid-sitting on the table were several paper plates holding leftovers from the previous day's meals. I observed an older man reach down and grab a red wiener and a piece of cold frybread from a high stack. The smell of grease and wet tobacco permeated the air.

I was greeted by my elder liaison's mom and was handed a mug of coffee that was pitch black and thick as syrup. The encampment slowly came to life, and I observed several people greet each other with a kiss. A Blackfoot scholar learned from an Indigenous elder that using a kiss, even between males, as a greeting, demonstrates a reinforcement of the value system (Pepion, 1999). I looked back towards the kitchen area and heard an older woman teach a young child about the taboos of using a knife to stir something in a pot on the Coleman stove. I learned during an earlier elder visit about the lessons taught at ceremonies:

We were raised to not cut our hair-and if we did it went to a special place; the same with our skin-right down to scratching our head we had to use a stick-you couldn't use your fingernails. We were taught you don't cut over an open flame with a knife-you don't lick a knife-you don't stir with a knife ... You don't stand up and eat-you know your protocol.

Even though it was in the middle of the summer, the morning air blowing off the mountains was crisp, and you needed to wear a light coat. The remnants of an early morning rain shower were still present on the tipis. I noticed that the material covering the tipi poles was stretched tightly and was placed about 6-inches above the ground leaving an opening around the tipi's entire circumference-I watched as field mice and gophers raced in and out of the gaps. 
My cultural journey would require me to sit for hours and listen to traditional stories, and at other times to sit in silence and observe the interactions between the young and old. My elder liaison greeted me with a nod of his head and tapping of his right hand on his heart. I had come to learn that the gesture of tapping your heart was a sign of respect and gratitude.

I positioned myself between two elders, who I noticed was watching a group of ceremonial bundle holders walked slowly around the grounds praying. One of the elders said softly, "Can you feel the spirits in the wind blowing off those mountains over there as he pointed in the direction of mountains?" I looked up at the mountains for few moments and then assuring him that I indeed could feel the stiff gusts of wind blowing in our faces. The other elder gave a short laugh and said, "No, can you feel the spirits in the wind?" Somewhat confused about the meaning of the question, I confessed that I was confused about the reference. The elder paused for a few moments, coughed, and then said, "When I breathe in the air coming off the mountains, my body fills with the spirits of my ancestors."

During a visit with an elder, I learned that the Blackfoot have interacted with the mountains since their genesis. Blackfoot elders believe they are the original inhabitants of this continent and their DNA is engrained in the landscape. Elders told us that they think there is overwhelming proof that the territory they claim is their traditional lands:

We have these buffalo jumps ... tipi rings ... medicine wheels all over ... and I think that's the archeological data that proves we've been here for a long time ... and that this is our territory ... Our Blackfoot ways are in our DNA-it's who you are meant to be-its right here in this land. The real people [Niitsitapi] that's who we are-the original from this continent. We have our own creation stories that come from right here in this place. Natoosii gave us our creation-our origin of how we were made ... When you go in all directions from this point you see the places we are entrusted to care for and they are ingrained in our DNA.

The Blackfoot have experienced a contentious relationship with governments for taking their territory to establish National Parks. Glacier National Park's landscape borders the Blackfeet Indian reservation and is believed sacred and central to defining Blackfoot cultural identity (Craig, Yung, \& Borrie, 2012). I listened to an elder tell me a story about the sacred sites trapped within Glacier National Park - the elder paused for several minutes and gathered her thoughts and emotions. I was starting to wonder if she had crossed over a forbidden cultural boundary. When she responded, she talked about the sanctity of land inside the park and how the government had taken it from them:

The area around and in the park holds many sacred places for us ... it is where we gathered roots and other vegetation for our medicines ... where we go to visit with our ancestors ... the stories of our beginning and our existence are tied to the mountains. 


\section{Methodology}

\section{Positionality}

Positionality is an essential concept for non-Indigenous scholars researching with Indigenous peoples to acknowledge. An argument made by Smith (2012) was that non-Indigenous scholars have traditionally shaped Indigenous-based examinations through a Western lens, ignoring the impacts of colonization. In contrast, we used a Blackfoot elder liaison to guide the first author throughout the study by identifying Indigenous elders, selecting traditional Blackfoot ceremonies to attend, and providing cultural clarification on research design, implementation, and clarifying results. The elder liaison is a ceremonial bundle holder and attends and participates in traditional Blackfoot ceremonies. We were granted permission to conduct this study by the Arizona State University Institutional Review Board and the Blackfeet Nation Institutional Review Board.

\section{Theoretical Lens}

We viewed the contents of article through the lens of Tribal Critical Race Theory (TribalCrit) (Brayboy, 2005). TribalCrit relies on philosophies born from Critical Race Theory (CRT). CRT places a theoretic emphasis on how race and racism are profoundly entrenched within the fibers of the United States and is situated on contemporary narratives about bias from the viewpoint of minorities, for the elimination of cultural suppression while concurrently acknowledging that race is a collective concept, and additional areas of distinction, such as sex, socioeconomic status, and any inequalities encountered by persons (Creswell, 2013; James, 2019). CRT's basic premise is that racism is endemic in society; whereas, the first tenet of TribalCrit is that colonization is endemic in society (Brayboy, 2005). Scholars noted that (TribalCrit) "emphasizes a desire to obtain and forge ... self-determination while confronting the influences of colonization, imperialism, white supremacy, and assimilation within educational contexts" (Stanton, Carjuzaa, \& Hall, 2019, p.80).

\section{Portraiture}

As two non-Indigenous scholars conducting this research, we must choose appropriate methods and be cautious in our interpretations. All scholars, whether conducting quantitative or qualitative examinations, influence the data they collect and interpret. The method that we used, portraiture, is no different in this sense and perhaps is even more evident as the researcher navigates the relationships with the participants to construct a narrative; at each stage of the study, the involvement of the portraitist as an instrument of inquiry is present. Although the portraitist's participation is evident and explicit when using portraiture, so too is their commitment to skepticism and critique. Lawrence-Lightfoot \& Davis (1997) suggested, "One might even say that because the self of the portraitist is so essential to the development of the work, she must be that much more vigilant about identifying other sources of challenge to her perspective" (p. 13). The portraitist acknowledges their positionality by recognizing that their values, life experiences, and biases influence what data is collected and the interpretations of research activities.

Lawrence-Lightfoot and Davis (1997) explained that a portraitist must map out the physical, historical, and personal contexts trapped in the research. Smith (1999) noted the importance of recognizing that Indigenous peoples have unique ways of viewing the world. The scholar mentioned that privileging the dominant group's ways of knowing promotes a lack of 
consideration as it relates to marginalized groups' ways of knowing and constructing and pursuing knowledge "is deeply embedded in multiple layers of imperial and colonial practices" (Smith, 1999, p. 2). Wilson (2008) stated, "Elders often use experiences from their own lives or others' lives to help counsel or teach" (p. 98). Elders served as both cultural guides and cultural teachers, and we relied on the words of Linda Tuhiwai Smith to guide discovery. Smith (1999) suggested:

It is not simply about giving an oral account or a genealogical naming of the land and the events which rages over it, but a very powerful need to give testimony to and restore a spirit, to bring back into existence a world fragmented and dying (p. 29-30).

To understand how Blackfoot elders viewed their "physical context," the first author listened for stories that opened a window into how they pulled their sacred knowledge from their landscape. These stories gave us insights into how elders positioned themselves within their physical environment and how they perceived the relationships between the land and spirituality. Lawrence -Lightfoot and Davis (1997) explicated that "historical context" refers to elders' "journey, culture, [and] ideology" (p. 52). To develop a historical understanding, the first author listened for stories about their cultural journey - what they learned from their ancestors about being Blackfoot and how that shaped their understanding of and connection to their culture. Finally, the first author listened intently for how they positioned themselves culturally within the "personal context" of the tribe and within the broader society.

\section{Elder Visits}

The cultural listening visits conducted by the first author included 26 formal and informal visits. The visits occurred at the homes of elders or historically significant sites determined by the elders. The informal visits occurred while attending and participating in traditional Blackfoot ceremonies located across the Blackfoot territory. The first author followed an interview guide for the formal visits to ensure data compatibility across the sample, but participants were encouraged to engage in a free-flowing conversation. Of the 26 elders, 15 were male, and 11 were female. The formal elder listening visits lasted from 45 minutes to nearly 3 hours (average $=81.25, \mathrm{SD}=37.48$ ), and informal interviews continued throughout his participation in traditional ceremonies. The visits were digitally recorded when permitted. The first author began each formal elder visit following local Indigenous protocol by explaining the purpose of our study and providing an honorarium of $\$ 50$, and a bag of pouch tobacco.

\section{Analytic Process}

We adhered to the belief that coding links pieces of data to provide the basis of an idea (Saldaña, 2013) as the foundation of our analysis. We used Blackfoot elders' statements and the first author's observations and participation in traditional ceremonies to build a deep understanding of how elders perceive traditional Blackfoot values.

Blackfoot culture prohibits using digital recording devices while attending ceremonies, so we relied on analytical memos pulled from field notes to capture the first author's experiences at ceremonies. Field notes contain observations the scholar captures, whereas analytic memos are the reflections and understandings the scholar has of the data. Saldaña (2013) maintained that an analytical memo process helps the researcher organize their thoughts and provides a roadmap for 
critically analyzing complex relationships between our personal views and how we interact with the data. Below is an example of an analytic memo created from field notes captured at the Akokatsin ceremony. An example of an analytical memo made from the following passage is below:

I was seated between two elders watching groups of bundle holders walk slowly around the grounds praying. A group of four rambunctious children passed in front of us throwing make-believe spears at imaginary animals. In the distance, the first author heard a soft voice come from one of the tipis: "little ones come here." The four children scooted towards a large tipi painted with colorful pictures of horses and mountains. An elderly lady stepped from the tipi, bent over, and greeted the children with a quick hug. She then said in a stern but loving voice said, "there are many people here praying to the Creator and we need to be respectful."

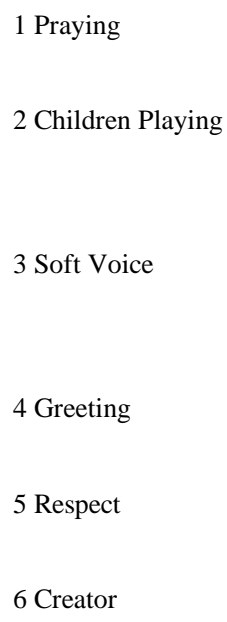

In this analytic memo the first author writes about how he felt when he heard the grandmother talking to the children:

I had a warm feeling when I heard the older women call the children to attention. Her voice reminded me of my grandma when we were camping and how she would talk to me when I was throwing things into the fire. I experienced a feeling of serenity and gained a deeper understanding of spirituality's importance when I heard her tell the young people they needed to respect their Creator (August 10, 2019).

To identify the traditional values voiced by elders, we used, in part, In Vivo Coding. In Vivo Coding uses the participants' exact words as codes instead of scholar-created codes (Saldaña, 2013). In Vivo Coding also aligns with our use of an Indigenous paradigm. The term Indigenous paradigm refers to the shared cultural attitudes and beliefs of Indigenous people. An Indigenous research paradigm serves to decolonize the marginalized voice by honoring an Indigenous worldview. Saldaña (2013) posited that In Vivo Coding relies in part, on using folk or indigenous terms. The scholar stated, "Folk or indigenous terms are participant-generated words from members of a particular culture, subculture, or microculture" (Saldaña, 2013, p. 91). Below is an example of our In Vivo Coding process from a passage captured during visits with elders:

The smoke goes through us to our Creator ... We smudge when we are going to connect with the spirit world ... The significance of the smudge is if you want to engage in that level of spirituality it opens it for you ... The time you have your sweats is when you want your prayers to be the strongest ... When you're struggling you go see an elderpray and light your smudge and it will take your prayers up. Even if you've never smelt sweetgrass it creates a calmness.

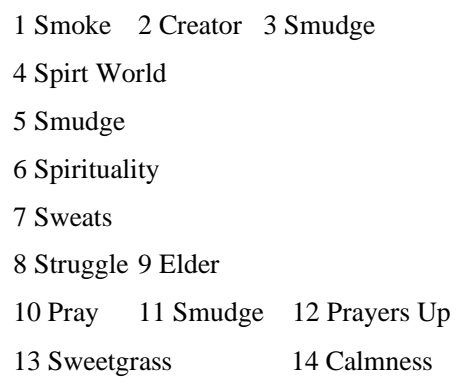


We also used the belief subcategory of value coding to identify how elders expressed traditional values. Saldaña (2013) claimed that value coding is beneficial when scholars are exploring "cultural values, identity, intrapersonal and interpersonal participant experiences and actions in case studies, appreciative inquiry, oral history, and critical ethnography" (p.111). At the beginning of this article, we indicated that we aimed to learn how Blackfoot elders perceived traditional values. We used the values identified in the Blackfeet Education Standards (BES) as a guide to developing our initial belief codes. The Blackfeet tribe adopted the BES in 2005 to integrate Blackfeet knowledge, language, and cultural benchmarks into educational programs located on the Blackfeet Indian Reservation. The BES foundation are Blackfeet values, defined as "standards or principles considered valuable or important for life" (p. 4). The framers of BES identified Blackfeet values as Honesty, Generosity, Respect, Spirituality, Courage, Humility, and Compassion (Hall, 2018). Below is an example of our Values Coding process with a passage captured during a visit with an elder:

We have a responsibility to treat each other with kindness and respect and to be thankful for the Creator giving the Blackfoot people courage to persevere. That is what you see at these ceremoniespeople praying together and helping one another get closer to our Creator.

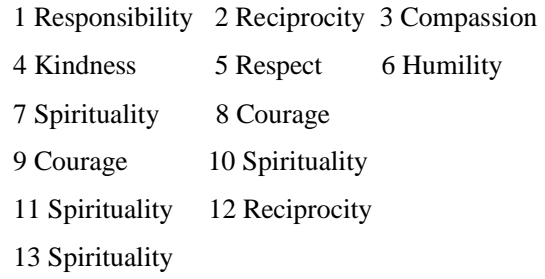

To demonstrate the interconnectivity between our codes and categories, we used an analytic codeweaving process, illustrated in Figure 1.

Figure 1

Analytic Codeweaving Process for Spirituality

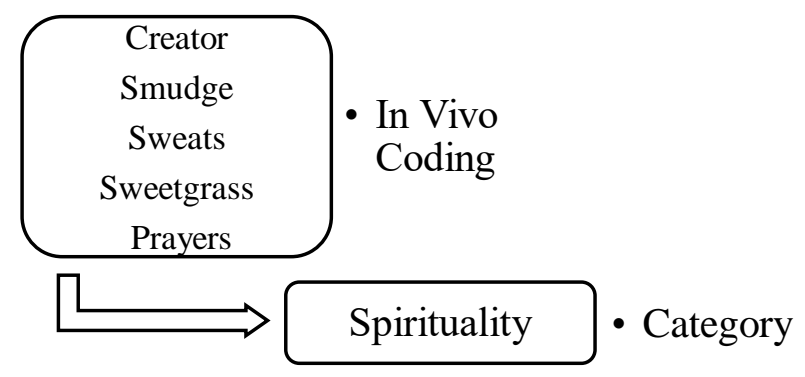

\section{Translating Values to Blackfoot Language}

Translating the values from the English language to the Blackfoot language was an essential part of our study. The struggle of coming to know how Blackfoot elders perceive their values is difficult to capture because their values are reflected through the Blackfoot language, but not in the way we understand words in the English language. An elder told us a story about the conflict of translating between the two languages: 
Translation is hard because most words in English are nouns and the expression is very rigid and set. In Blackfoot, most words are verbs and are fluid. Blackfoot is a language that reacts with the world around us in a fluid manner. A person that wants to translate words has to understand both languages and how to express these words in two different sets of reality.

When asked what the Blackfoot word for responsibility would be, the same elder said:

It's kind of hard to say what responsibility translates to in Blackfoot. Iipoohsapihtsiiwa - literally means it's my direction but can be said to mean it's up to me. Nita'po'takssin - it's my work. Nomohpsskssksimo'tookowa - I was given the authority/responsibility to take care of this. As you can see there are a number of ways to say it.

When requesting a translation for the values of generosity and kindness, we noticed that the same Blackfoot word (ăa"sitǔpiiiyissin) was provided for both even though elders clearly expressed a difference between the two values. We discovered that elders could tell the difference between the two words based on the circumstances each word is experienced:

Well, you see that the Blackfoot word for generosity and kindness is the same but the meaning of the two words are different to us based on the situation we are experiencing the actions of the words. Like if you're at ceremony you could ask an elder to show you the difference between generosity and kindness and they can show you.

The elder liaison explained through a personal story the difficulty of transitioning between an English language mindset and a Blackfoot language mindset:

The problem is because for myself I try to put it in thinking in English, whereas a fluent Blackfoot speaker puts it in Blackfoot thinking-like moose. The fluent speaker already knows it doesn't mean moose-A lot of people say: How do you say moose in Blackfoot? It doesn't mean moosemy grandpa said it means long black nose coming — that's what he referred to it as, but I'm trying to think of it in English and Western concepts. These young kids that are learning the language have an advantage to people like me whose brains have already been washed of how to think Blackfoot. Speakers say think like a Blackfoot not like a Westerner.

The ten traditional values identified are presented in both English language and Blackfoot language and include: Respect (iiyināakoǒtsiiyissin), Gratitude (ksimmătsiitsiiyissin), Responsibility (ăatsimmittǔpiiyissin), Humility (măatsstŭtsiittǔpii), Kindness (ăa"sittǔpiiiyissin), Honesty (mōkăamō•tsittǔpiiyissin), Reciprocity (isspoōmm'taittǔpiiiyissin), Compassion (kimmăpiipittssin), Courage (iiyikittǔpiiiyissin), and Generosity (ăa"sitǔpiiiyissi). The traditional values are shown in the Hoop of Traditional Blackfoot Values identified in Figure 2. 


\section{Figure 2}

\section{The Hoop of Traditional Blackfoot Values}

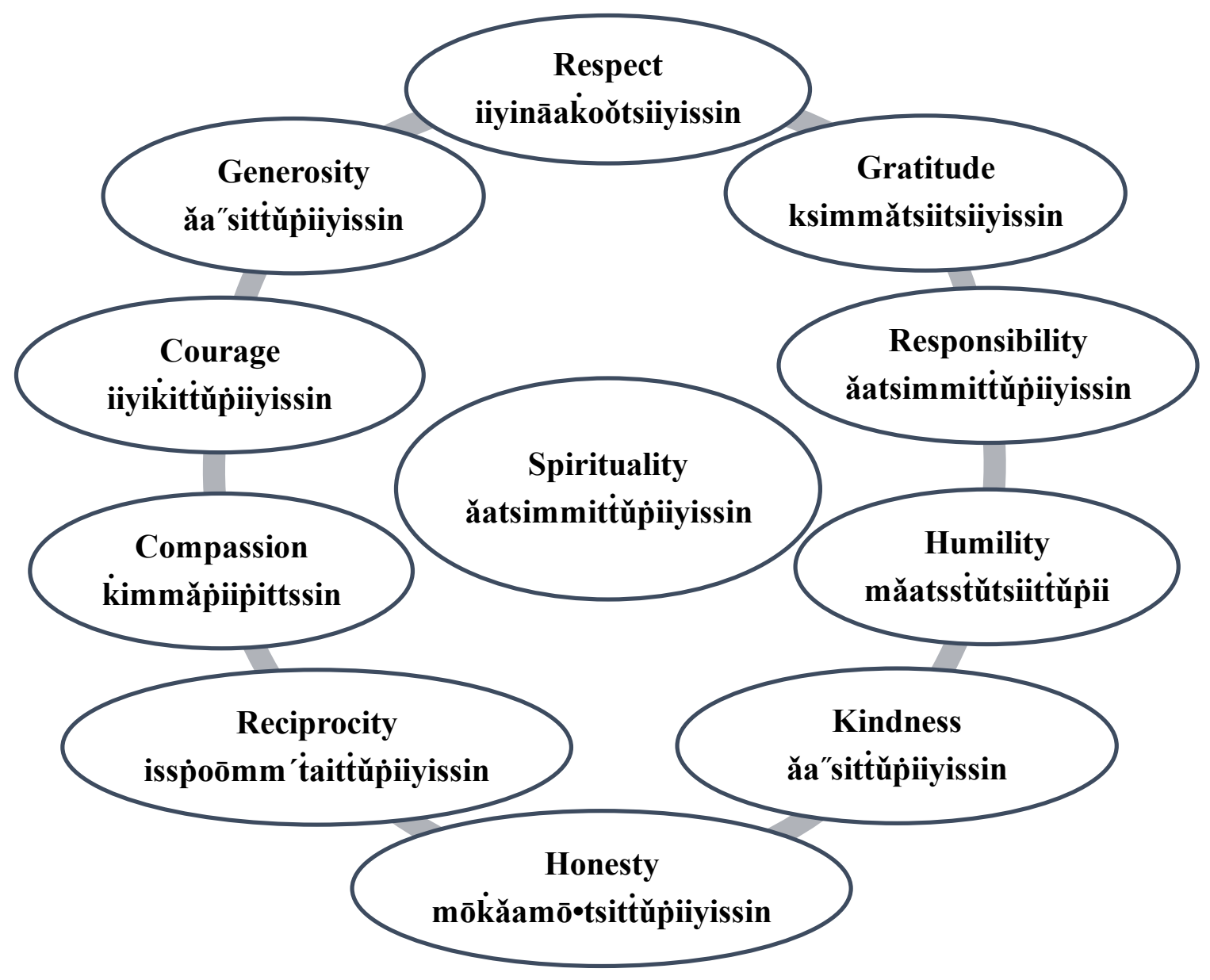

\section{Discussion}

The goal of our investigation was to gain an understanding of how Blackfoot elders perceive traditional values. Following years of repression and social inequality, countless colonized Indigenous societies are pursuing to resurrect traditional values (Simpson, 2009). Sustaining an Indigenous worldview is critical for avowing self-rule and Indigenous culture to preserve and flourish inside its unique values (Gladstone \& Pepion, 2016).

Some scholars described culture as beliefs or behaviors transferred between generations by applying traditional values (Carter, 2000; Demmert \& Towner, 2003; Gutierrez \& Rogoff, 2003; Lee \& Buxton, 2010; Nayar \& Wright, 2020). The clash between gaining individual rights while surrendering self-determination would alter how Indigenous people transferred their way of knowing to future generations causing Indigenous people to lose parts of their cultural identity (Brave Heart, \& De Bruyn 1998).

A Blackfoot scholar suggested that prior scholars have denied Blackfoot elders the opportunities to share their wisdom, stating, "There is no documented evidence that the elders of the tribe have been included in giving input, ideas, and recommendations toward the transfer of tribal knowledge" (Still Smoking, 1997, p.16). In contrast, we relied on our visits with Blackfoot elders, and by attending and participating in Blackfoot ceremonies to chronicle stories and create 
the Hoop of Traditional Blackfoot Values. One scholar suggested that capturing the stories of tribal elders is a worthy endeavor that can assist with cultural preservation that allows for the transfer of values that otherwise would be lost with elders' passing (Repp, 2009).

During my visits with elders, I was intrigued to discover how they described their understanding of values. Specifically, what comes to mind when they hear the phrase traditional Blackfoot values? - the concept of values was familiar to most elders, but how they came to know and understand their values transcended a contemporary interpretation. The Merriam-Webster online dictionary defines value as "something (such as a principle or quality) intrinsically valuable or desirable." The responses we gathered from the elders align with aspects of the definition offered through the Merriam-Webster online dictionary. Still, it is the interpretation of the phrase "intrinsically valuable or desirable" that separates their understanding. The elders I visited with used words like survival and extinct to describe their knowledge and reliance on values.

Native Americans traditionally lived in small groups and had to rely on each other for their survival. Elders conveyed the importance of teaching their young about survival values and how they had to be courageous and demonstrate compassion and humility to survive:

We lived in small bands and in order to survive we had to practice and teach our young people to rely on our survival values ... words like courage and compassion and humility are part of who we are as a people. We had to trust each other ... Native Americans lived in small groups-and to ensure their survival they had to teach their kids to be resourceful, to be honest, to be courageous, because they had to fight off enemies, they had to provide for everybody, so they had to be generous. You must teach your children to be your elders-your caretakers in your old age-that's why we have these values-for survival, because survival was the ultimate goal ... Our people faced many years of atrocities and if we wouldn't have taught our young people to be courageous and to sacrifice for the good of everyone, we would have been extinct.

Indigenous people have relied on traditional values to overcome centuries of oppression (Vizenor, 2008; Burnette \& Figley, 2017). Often, Indigenous values connect to the cosmos, "a harmony of the individual with the tribe, the tribe with the land, and the land with the spirit of the universe" (Duran, 2002, p. 1) and chief to this pursuit for the accord is a feeling of reliability -the agelessness and certainty of nature as the underpinning of life. This pattern represents infinity- a single truth, and it exceeds all in its completeness, offering reverence to all that exists (Herring, 1989). We also learned that many elders in our study connected their understanding of Blackfoot values with their life cycle. A Blackfoot elder explained the connection this way:

There was a hand in the sky, and the stars all connects in one way or another... the physical part is not only in the land but in the cosmos as well. That's where we become the people that are connected to the stars and connected to the universe that way-that's how we got here.

Scholars indicated that being able to contextualize traditional values in their situated place is compulsory for creating a sense of belonging, resulting in developing strong resiliency skills (Wang, Zhang, \& Zimmerman, 2015; Greene, 2010). A strong sense of belonging is related to cultural associations' strength and a sense of connectedness with an individual's tribal history 
(Garrett \& Garrett, 1994) that helps Indigenous people develop resiliency skills (Whitbeck, Chen, Hoyt, \& Adams, 2004), bringing them closer to tribal sovereignty.

We learned from Blackfoot elders that ceremonies are where Blackfoot children come to know their values - come to learn about their tasks and how they connect to their Creator. Blackfoot scholars indicated that traditional Blackfoot learning starts with parents teaching their infants before being shifted to grandparents (Pepion, 1999; Bastien, 2004), where their histories, cultures, and traditional knowledge are transferred (Hall, 2018; Bastien, 2004; Pepion, 1999) through ceremonies, and traditional storytelling (Juneau, 2001).

The time spent with grandparents is vital as traditional values transfer between generations (Hall, 2018; Bastien, 2004; Pepion, 1999). Our study reveals that Blackfoot elders build upon the extended system model (Red Horse, 1980) by modeling traditional values at ceremonies. The first author experienced this firsthand while attending a Blackfoot ceremony, observing a grandmother redirecting her rambunctious grandchildren by explaining to them the importance of respecting their Creator. Other scholars investigating Indigenous peoples also identified the significance of grandparents modeling traditional values (Dennis, Kepple \& Brewer II, 2017). Many of the elders in our study talked about the importance of grandparents teaching their young about survival.

Elders in our study indicated that they believe their values and traditional Indigenous belief systems are intertwined, and it is in that braiding where their sacred knowledge is stored-their pathway for survival is found in their values which are the foundation of their knowledge:

The diseases-the smallpox-measles-tuberculous-starvation-the relationships with governments-the rations - the broken promises of treaties-Christianity and the massacres all had an impact on our values. This has been our strength to survive ... as infants we are learning our value system and belief system and about our elders and the spiritualitywhat do we hold sacred? How does our way continue? ... where does it live? It lives in a value system and belief system that teaches us what is sacred knowledge and what is traditional knowledge.

Indigenous people experienced forced colonization that tore away pieces of their identity, where their beliefs were deemed appalling, offensive, repugnant, and medieval (Smith, 1999). The intentional acts aimed to crush their cultural spirit and damaged their ability to transfer their values between generations. The United States government forced Indian children, often through military intervention, into boarding schools, where they were disciplined for speaking their Native language or practicing their culture (Deloria, 1988, [1969]). The assimilation policies of the 1880s and the establishment of the boarding school era created an American Holocaust (Brave Heart \& De Bruyn, 1998). Elders in our study highlighted the lasting ramifications of cultural discontinuity caused by colonization:

A child's grandparents have the responsibility to pass along our survival values so that our young can carry on our traditions... We are the first age group of parents that didn't have to surrender our children to the residential schools... what was our existence? If you look at this Indian policy to rid the Indian of their identity-this was the whole goal. You accomplished this by separating the parents from the children, so the parents no longer have influence of the child. This becomes a timeline that you can see the disconnect of family. When you talk about the continuity 
you can see the collapse - and you can see the spiritual abuse, the physical abuse - sexual abuse - and the loss of self-respect-so how can you expect moms and dads to do great things when that's been their experience? When we talk about genocide the definition is to extinguish the culture through the children. We have to know that there was a deliberate breakdown of the family and the extended family and it harmed the value system and personal identity.

A review of a Voucher of Disinterested Persons used as the basis for an application of an Indigenous child to the Carlisle Indian Industrial School uncovers a statement capturing the evil mindset expressed towards American Indians, explicitly stating, "Under present circumstances, she is thrown in with others who consider her as an inferior race and whose influence will be morally bad for her." The Vouchers of Disinterested Persons and the Carlisle Indian Industrial School application are attached as Appendix B.

The Carlisle Indian Industrial School was established in 1879 by Richard Pratt with financial support from the United States government. The school was used as a social experiment to assimilate Native Americans (Satterlee, 2002). Pratt believed that to achieve complete assimilation, Indigenous children needed to be moved a great distance from their families, denied access to their traditions and cultures, and indoctrinate in Anglo-American ways (Fear-Segal, \& Rose, 2016). By 1889, nearly 50 Blackfoot children attended the Carlisle Indian Industrial School (Still-Smoking, 1997).

Boarding schools intended to strip Indigenous children of their identity by eradicating their Native language seen as an impediment to complete assimilation, cutting their hair, changing their names, preventing them from wearing traditional clothing in exchange for military uniforms, and forcing them to adopt the tents of Christianity (Johnston-Goodstar \& Roholt, 2017; CharbonneauDahlen, Lowe, \& Morris, 2016; Fear-Segal, \& Rose, 2016). We learned from elders that the attack on the language caused cultural confusion that continues to impact Indigenous people striving to learn traditional values:

We are from an era where our parents and grandparents didn't teach us Blackfoot because they feared we would be punished at the boarding schools ... The punishments were severe for speaking the language like forced starvation ...

The importance of sustaining traditional language is essential to cultural identity and Native American community sustainability (Searle et al., 2018) because embedded in the language are the life-sustaining elements of understanding ceremonial practices that are the bedrock of Native peoples' identity (Benally \& Viri, 2005). Stories about the connection between Blackfoot language and spirituality was a common theme we heard from elders:

The language is where our culture lives-it's where the sacred traditions are understood and experienced. If you go to ceremony, you'll hear prayer-you'll hear song-all in Blackfoot—it's because that's how our Creator notices us ... 
Boarding schools promoted cultural extinction (Adams, 1995) by dismissing the traditions of storytelling and oral history, resulting in their cultural identity being understood through their colonizers' lens (Paris \& Alim, 2014). The oral histories expressed through stories were indispensable aspects of acquiring sacred knowledge and understanding one's kinship alliances (Hubbard, 2016), and through these relationships, a Blackfoot comes to know. Scholars indicate that storytelling is a legitimate source of transferring Tribal philosophies, beliefs, and traditions between generations (Brayboy, 2005). Indigenous peoples' history contains traditional stories rooted with origin legends where Indigenous children learn about their heroes and heroines and the lessons they used to survive (Raymond, 1999).

\section{Conclusion}

The scholars of this current study were concerned with assuring that the methodologies used honored the participants' words', values and worldviews. Decolonizing the story is critical in using an Indigenous research paradigm to include the participants as co-researchers. For scholars to decolonize the word, they must acknowledge that oppressors frequently alter the meaning of words to fit their worldviews. The oppressor's language puts the oppressed in a linguistic box that denies them their linguistic skills and forces them to adopt the oppressor's language as a form of control (Chilisa \& Tsheko, 2014).

Decolonization is a complex process that not only looks at political structures but also identifies the importance of rewiring the mind and the spirit so that the soul is cleansed (Battiste, Bell, \& Findley, 2002), and rejects the idea that the cultural traits of the dominant culture are transferred to other cultures (Coleman et al., 2012). Smith (1999) and Pidgeon (2008) suggested that researchers have customarily preferred ways of knowing developed primarily by colonizers. Simply put, the colonizers' have privileged their ways of knowing and building knowledge.

We were mindful of decolonizing the word when we selected portraiture and cultural listening as our methods. When scholars capture another person's story by listening, the storyteller is no longer in control of how that story gets retold by the scholar. Acting in our role as a portraitist, we were mindful of the storyteller's original intent and our responsibility of retelling the stories. However, we acknowledge that our worldviews influence our interpretations, as do our readers' worldviews, who become active contributors to telling the final story (Lawerence-Lightfoot, \& Davis, 1997).

\section{References}

Absolon, K. (1993). Healing as practice: Teachings from the Medicine Wheel [Unpublished manuscript]. WUNSKA Network, Canadian Schools of Social Work.

Absolon, K. (2010). Indigenous wholistic theory: A knowledge set for practice. First Peoples Child \& Family Review, 5(2), 74-87. https://doi.org/10.7202/1068933.

Adams, D. W. (1995). Education for extinction: American Indians and the boarding school experience. University Press of Kansas.

Akee, R. (2020). Land titles and dispossession: Allotment on American Indian reservations. Journal of Economics, Race and Policy, 3, 123-143. https://doi.org/10.1007/s41996-01900035-z.

Archibald, J. (2008). Indigenous storywork, educating the heart, mind, body, and spirit. UBC Press.

Barsh, R., L., \& Marlor, C. (2003). Driving bison and Blackfoot science. Human Ecology, 31(4), 571-593. https://doi.org/10.1023/B:HUEC.0000005514.93842.91. 
Bassett, D., Tsosie, U., \& Nannauck, S. (2012). Our culture is medicine: Perspectives of Native healers on post trauma recovery among American Indian and Alaska Native patients. The Permanente Journal, 16(1), 19-27. doi:10.7812/tpp/11-123.

Basso, K., H. (1996). Wisdom sits in places: Landscape and language among the Western Apache. University of New Mexico Press.

Bastien, B. (2004). Blackfoot Ways of Knowing: The Worldview of the Siksikaitsitapi. University of Calgary Press.

Battiste, M., Bell, L., \& Findlay, L. M. (2002). An interview with Linda Tuhiwai Te RinaSmith. Canadian Journal of Native Education, 26(2), 169-201.

Benally, A., Vira, D. (2005). Dine Bizaad (Navajo language) at a crossroads: Extinction or renewal? Bilingual Research Journal, 29(1), 85-108. https://doi.org/10.1080/15235882.2005.10162825.

Bobroff, K., H. (2001). Retelling allotment: Indian property rights and the myth of common ownership. Vanderbilt Law Review, 54(4), 1559-1623.

Brave Heart, M.Y.H., \& De Bruyn, L. (1998). The American holocaust: Historical unresolved grief among Native American Indians. American Indian and Alaska Native Mental Health Research Journal, 8(2), 56-78.

Brayboy, B. M. J. (2013). Tidemarks and legacies: Building on the past and moving to the future. Anthropology \& Education, 44(1), 1-10. https://doi.org/10.1111/aeq.12001.

Brayboy, B., M., J. (2005). Toward a tribal critical race theory in education. Urban Review, 37(5), 425-446. https://doi.org/10.1007/s11256-005-0018-y.

Burnette, C. E., \& Figley, C. R. (2017). Historical oppression, resilience, and transgender: Can a holistic framework help explain violence experienced by Indigenous people? Social Work, 62(1), 37-44.

Calderon, D., (2014). Speaking back to manifest destines: A land-education-based approach to critical curriculum inquiry. Environmental Education Research, 20(1), 1-13. https://doi.org/10.1080/13504622.2013.865114.

Carbaugh, D. (1999). Just listen: Listening and landscape among the Blackfeet. Wester Journal of Communication, 63(3), 250-270. https://doi.org/10.1080/10570319909374641

Carter, R.T. (2000). Reimagining race in education: A new paradigm from psychology. Teachers College Record, 102(5), 864-897.

Charbonneau-Dahlen, B., Lowe, J., \& Morris, S. (2016). Giving voice to historical trauma through storytelling: The Impact of boarding school experience on American Indians. Journal of Aggression, Maltreatment \& Trauma, 25(6), 598-617. https://doi.org/10.1080/10926771.2016.1157843.

Chilisa, B., \& Tsheko, N., G. (2014). Mixed methods in indigenous research: Building relationships for sustainable intervention outcomes. Journal of Mixed Methods Research, 8(3) 222-233. https://doi.org/10.1177/1558689814527878.

Clark, S., D. (2020). The role traditional American Indian values play in fostering cultural connectedness and school connectedness in American Indian youth: Experienced through a Blackfoot way of knowing paradigm (Publication No. 280022150) [Doctoral dissertation, Arizona State University]. [ProQuest Dissertations Publishing].

Coleman, D., Battiste, M., Henderson, S., Findlay, M., I., \& Findlay, L. (2012). Different knowings and the indigenous humanities. English Studies in Canada, 38(1), 141-159.

Cook-Lynn, E. (2006). The power of horses and other stories. University of Arizona Press. 
Craig, D., R., Yung, L., \& Borrie, W., T. (2012). Blackfeet belong to the mountains: Hope, loss, and Blackfeet claims to Glacier National Park. Conservation and Society, 10(3), 232 - 242. https://www.jstor.org/stable/26393080.

Crawford A. (2014). The trauma experienced by generations past having an effect in their descendants: Narrative and historical trauma among Inuit in Nunavut, Canada. Transcultural Psychiatry, 51(3), 339-369. https://doi.org/10.1177/1363461512467161.

Creswell, J.W. (2013). Qualitative inquiry \& research design: choosing among the five approaches. SAGE Publications, Inc.

Crowshoe, R., \& Manneschmidt, S. (2002). Akak'stiman: A Blackfoot framework for decisionmaking and mediation process. University of Calgary Press.

Dapice, A. (2006). The medicine wheel. Journal of Transcultural Nursing, 17(3), 251-260.

Deloria, V., Jr. (1969). Custer died for your sins. Macmillan Press.

Demmert, W., \& Towner, J. (2003). A review of the research literature on the influences of culturally based education on the academic performance of Native American students. Northwest Regional Education Laboratory.

Dennis, M., Kepple, N. J., Brewer, J. (2017). Grandparents of the community: Lakota elders' view of intergenerational care. Grand Families: The Contemporary Journal of Research, Practice and Policy, 4(1), 115-142.

Dippel, C., \& D. Frye (2020). The effect of land allotment on Native American households during the assimilation era. Technical report, Working Paper.

Duran, B. (2002). American Indian Belief Systems and Traditional Practices. The University of Oklahoma.

Duran, E. and Duran, B. (1995) Native American postcolonial psychology. State University of New York Press, Albany, 1 - 221.

Eli, S., K. (2013). Piikanaikiiks: A literary analysis of Blackfoot oral stories and the traditional roles of women in leadership (Publication No. 10133/3572) [Doctoral dissertation, University of Lethbridge]. ProQuest Dissertations Publishing.

Ewers J.C. (1958). The Blackfeet: Raiders on the Northwestern Plains. University of Oklahoma Press.

Ewers, C., J. (1958). The Blackfeet: Raiders of the northwest plains. University of Oklahoma Press.

Fear-Segal, J., \& Rose, S., D. (2016). Carlisle Indian industrial school: Indigenous histories, memories, and reclamations. University of Nebraska Press.

Garrett, J. T. and Garrett, M. W. (1994). The Path of Good Medicine: Understanding and Counseling Native American Indians. Journal of Multicultural Counseling and Development, 22(3), 134-144. https://doi.org/10.1002/j.2161-1912.1994.tb00459.x

Gladstone, J. S., \& Pepion, D. D. (2016). Exploring traditional Indigenous leadership concepts: A spiritual foundation for Blackfeet leadership. Leadership, 13(5), 571-589. doi.org/10.1177/1742715016638913.

Gone, J. P. (2013). Redressing First Nations historical trauma: Theorizing mechanisms for indigenous culture as mental health treatment. Transcultural Psychiatry, 50(5), 683-706. https://doi.org/10.1177/1363461513487669.

Greene, R. (2010). A study of holocaust survivors: Implications for curriculum. Journal of Social Work Education, 46, 293-303. doi:10.5175/JSWE.2010.200900055

Greider, T. and L. Garkovich. 1994. Landscapes: The social construction of nature and the environment. Rural Sociology $\quad$ 59(1), https://doi.org/10.1111/j.15490831.1994.tb00519.x.

Grinnell G., B. (1892). Early Blackfoot history. American Anthropologist, 5(2), 153-164. 
Grinnell G., B. (1962). Blackfoot lodge tails: The story of a prairie people. University of Nebraska Press.

Gutierrez, K. D., \& Rogoff, B. (2003). Cultural ways of learning: Individual traits or repertoires of practice. Educational Researcher, 32: 19-25.

Hall, B. (2018). Piikani School Leadership. [Unpublished doctoral dissertation]. Montana State University.

Harjo, L., D., Burhansstipanov, L., \& Lindstrom. (2014). Rationale for cultural Native patient navigators in Indian country. Journal of Cancer Education; 29(3), 414-419. doi:10.1007/s13187-014-0684-0.

Hernandez, N. (1999). Mokakssini: Blackfoot Theory of Knowledge. UMI Company.

Herring, R. D. (1989). The American Native family: Dissolution by coercion. Journal of Multicultural Counseling and Development, 17(1), 4-13. https://doi.org/10.1002/j.21611912.1989.tb00411.x.

Hill, D., L. (2006). Sense of belonging as connectedness, American Indian worldview, and mental health. Archives of Psychiatric Nursing, 20(5), 210-216. DOI: 10.1016/j.apnu.2006.04.003.

Houston, C., S., \& Houston, S. (2000). The first smallpox epidemic on the Canadian plains: In the fur-trader's words. The Canadian Journal of Infectious Diseases, 11(2), 112-115. doi: $10.1155 / 2000 / 782978$.

Hubbard, T. (2016). The Call of the Buffalo: Exploring Kinship with the Buffalo in Indigenous Creative Expression [Unpublished doctoral thesis]. University of Calgary.

Jackson, J.C. 2000. The Piikani Blackfeet: A culture under siege. Mountain Press.

Jackson, L., J., Coleman, J., Strikes with A Gun, G., \& Sweet Grass, D. (2015). Threading, stitching, and storytelling: Using CBPR and Blackfoot knowledge and cultural practices to improve domestic violence services for indigenous women. Journal of Indigenous Social Development, 4(1), 1-27.

James, W. Y. (2019). Imprint of Racism: White Adult Males' Transformational Experience from Racial Antipathy to Racial Reconciliation. American Journal of Qualitative Research, 3(1), 93-116. https://doi.org/10.29333/ajqr/5813

Johnston-Goodstar, K., \& VeLure Roholt, R. (2017). “Our kids aren't dropping out; they're being pushed out": Native American students and racial microaggressions in schools. Journal of Ethnic \& Cultural Diversity in Social Work: Innovation in Theory, Research \& Practice, 26(1-2), 30-47. https://doi.org/10.1080/15313204.2016.1263818.

Juneau, S. (2001). History and foundation of American Indian education. Montana Office of Public Instruction.

Kimmerer, R., W. (2013). Braiding sweetgrass. Milkweed.

Lawrence-Lightfoot, S., \& Davis, J. H. (1997). The Art and science of portraiture. San Francisco: Jossey-Bass.

Lee, J., B. (2002). Fractionated heirship: A Blackfeet case study (Publication No. 4778) [Master's dissertation, University of Montana]. Scholarworks Dissertation Publishing.

Lee, O., \& Buxton, C. (2010). Diversity and Equity in Science Education. Teachers College Press.

Lokensgard, K. (2001). Gift and commodity [Unpublished doctoral dissertation]. Syracuse University.

Long Standing Bear Chief. (1992). Ni-KSO-Ko-Wa: Blackfoot spirituality, traditions, values and beliefs. Spirit Talk Press. 
Lowe, J., \& Struthers, R. (2001). A conceptual framework of nursing in Native American culture. Journal of Nursing Scholarship, 33(3), 279-283. https://doi.org/10.1111/j.15475069.2001.00279.x.

Mayor, A. (1995). The Nessus shirts in the new world: Smallpox blanket in history and legend. The Journal of American Folklore, 108(427), 54-77. https://doi.org/10.2307/541734.

McClintock, W. (1968). The Old North Trail: Life, legends, and religion of the Blackfeet Indians. University of Nebraska Press.

McClintock, W. (1999). The Old North Trail: Or, the life, legends, and religion of the Blackfeet Indians. University of Nebraska Press.

Merriam-Webster. (n.d.). Empathy. In Merriam-Webster.com dictionary. Retrieved April 20, 2021, from https://www.merriam-webster.com/dictionary/empathy.

Merriam-Webster. (n.d.). Value. In Merriam-Webster.com dictionary. Retrieved April 20, 2021, https://www.merriam-webster.com/dictionary/value.

Meyer, M., A. (2009). Indigenous and authentic: Hawaiian epistemology and the triangulation of meaning. In N.K. Denzin, Y.S. Lincoln \& L.T. Smith (Eds.). Handbook of critical and indigenous methodologies. (pp. 217-232). Sage.

Micmac and Maliseet Nation News (1992). Native Spirituality. Micmac and Maliseet Nation News, $3(9), 30$.

Miyashita, M., \& Chatsis, A. (2013). Collaborative development of Blackfoot language courses. Language Documentation\& Conservation, 7,302-330.

Nayar, S., \& Wright St.Clair, V. (2020). Multiple Cultures - One Process: Undertaking A Cross Cultural Grounded Theory Study. American Journal of Qualitative Research, 4(3), 131145. https://doi.org/10.29333/ajqr/9310

Paris, D., \& Alim, H., S. (2014). What are we seeking to sustain through culturally? responsive pedagogy? A loving critique forward. Harvard Educational Review, 84(1), 85-100.

Pepion, D. (1999). Blackfoot ceremony: A qualitative study of learning [Unpublished doctoral dissertation]. Montana State University.

Pepion, D., D. (2013). Ethnography of one family on a 1939 Blackfeet Indian reservation farm project in Montana. Great Plains Quarterly 33(3), 23-140.

Pewewardy, C. D. (1994). Culturally responsible pedagogy in action: An American Indian magnet school. In E. R. Hollins, J. E. King, \& W. C. Haymon (Eds.), Teaching diverse populations: Formulating a knowledge base (pp. 77-92). State University of New York Press.

Pidgeon, M. (2008). Pushing against the margins: Indigenous theorizing of success and retention in higher education. Journal of College Student Retention, 10(3), 339-360. https://doi.org/10.2190/CS.10.3.

Portman, A., A., \& Garrett, T., M (2006). Native American healing traditions. International Journal of Disability, Development and Education, 53(4), 453-469. https://doi.org/10.1080/10349120601008647.

Portman, T., A., A. (2001). Debunking the Pocahontas paradox: The need for a humanistic perspective. Journal of Humanistic Counseling, Education and Development, 40(2),18599. https://doi.org/10.1002/j.2164-490X.2001.tb00116.

Pratto, F., \& Stewart, A.L. (2011). Social dominance theory. The Encyclopedia of Peace Psychology. doi:10.1002/9780470672532.wbepp253.

Raymond, C. (1999). American Indian education: The terror of history and the nation's debt to the Indian peoples. University of Arkansas at Little Rock Law Review, 21(4), 941-977.

Red Horse, J. G. (1980). Family structure and value orientation in American Indians. Social Casework, 61(8), 462-467. 
Regular, K., W. (2009). Neighbours and networks: The Blood tribe in the southern Alberta economy, 1884-1939. University of Calgary Press.

Repp, D. (2009). Inscribing the raw materials of history: An analysis of the Doris Duke American Indian oral history program (Publication No. 3391846) [Doctoral dissertation, Arizona State University]. ProQuest Dissertations Publishing.

Saldaña, J. (2013). The coding manual for qualitative researchers (2nd ed.). Sage.

Satterlee, A. (2002). The Carlisle Indian industrial school. Educational Resources Information Center.

Searle, K. A., Casort, T., Litts, B. K., Brayboy, B., Dance, S. L. \& Kafai, Y. (2018). Cultural repertoires: Indigenous youth creating with place and story. Proceedings of International Conference of the Learning Sciences, ICLS. http://stelar.edc.org/publications/culturalrepertoires-indigenous-youth-creating-place-and-story.

Shebitz, D., J., \& Kimmerer, R., W. (2004). Population trends and habitat characteristics of sweetgrass, Anthoxanthum nitens: Integration of traditional and scientific ecological knowledge. Journal of Ethnobiology, 24(1), 93-111.

Sidanius, J., \& Pratto, F. (1999). Social dominance: An intergroup theory of social hierarchy and oppression. Cambridge University Press.

Sidanius, J., Pratto, F., \& Mitchell, M. (1994). In-group identification, social dominance orientation, and differential intergroup social allocation. Journal of Social Psychology, 134(1), 151-167. https://doi.org/10.1080/00224545.1994.9711378.

Simpson, M. (2009). Museums and restorative justice: heritage, repatriation and cultural education. Museum International, 61(1-2), 241-242. https://doi.org/10.1111/j.14680033.2009.01669.

Smith, L., T. (1999). Decolonizing methodologies: Research and indigenous peoples. Zed Books.

Smith, L., T. (2012). Decolonizing methodologies: Research and Indigenous peoples ( $2^{\text {nd }}$ Edition). Zed Books.

Stanton, C., R., Carjuzza, J., \& Hall, B. (2019). The promises, purposes, and possibilities of Montana's Indian education for all. Journal of American Indian Education, 58(3), 78-104. https://doi.org/10.5749/jamerindieduc.58.3.0078.

Still Smoking, D. (1997). Tribal education: A case study of tribal elders [Unpublished doctoral dissertation]. Montana State University.

Strayhorn, T. L., Bie, F., Dorime-Williams, M. L., \& Williams, M. S. (2016). Measuring the influence of Native American college students' interactions with diverse others on sense of belonging. Journal of American Indian Education, 55(1), 49-73. https://doi.org/10.5749/jamerindieduc.55.1.0049.

Struthers R. (2000). The lived experience of Ojibwa and Cree women healers. J Holist Nurs., 18(3), 261-79. doi: 10.1177/089801010001800307. PMID: 11847813.

Struthers, R., Lauderdale, J., Nichols, L., Tom-Orme, L., \& Strickland, C. (2005). Respecting tribal traditions in research and publications: Voices of five Native American nurse scholars. Journal of Transcultural Nursing, 16(3), 193-201.

Taylor, L., M. (2012). Old medicine women anew: Reimaging and reimagining the Blackfeet Matoki. Journal of Religion, Spirituality \& Aging, 25(1), 36-51. https://doi.org/10.1080/15528030.2013.738586.

Vizenor, G. (2008). Survivance: Narratives of native presence. University of Nebraska Press.

Wang, J.-L., Zhang, D.-J., \& Zimmerman, M. A. (2015). Resilience theory and its implications for Chinese adolescents. Psychological Reports, 117(2), 354-375. doi.org/10.2466/16.17.PR0.117c21z8. 
Whitbeck, L., Adams, G., Hoyt, D., and Chen, X. (2004). Conceptualizing and measuring historical trauma among American Indian people. American Journal of Community Psychology, 33(3), 119-130. 0091-0562/04/0600-0119/0.

Wilson, S. (2008). Research is Ceremony. Fernwood Publishing.

Wissler, C. (1912). Ceremonial bundles of the Blackfoot Indians. Anthropological Papers of the American Museum of Natural History, 7(2). New York.

Zedeño, M. N. (2017). Bison hunters and the Rocky Mountains: An evolving partnership. Quaternary International: 461, 80-101. https://doi.org/10.1016/j.quaint.2017.06.043.

Zedeño, M., N. (2008). Bundled Worlds: The Roles and Interactions of Complex Objects from the North American Plains. Journal of Archaeological Method and Theory, 15(4), 362 - 378.

\section{Notes on Contributors}

Shawn Clark (Ed.D.) was a public-school educator for over 25-years. Shawn earned his Ed.D. in Education (Leadership and Innovation) at the Mary Lou Fulton Teachers College at Arizona State University. Shawn began his education career teaching in school systems located on or bordering Indian reservations. Shawn also served as a building level administrator for 19-years, including seven years at the largest Indigenous student attended school in Montana. Shawn concentrates his research around Native American populations that contributes to culturally sustaining and revitalizing communities. Shawn is an assistant professor of education at the University of Providence and the founder of iinii.org. and iTASSEL.org. ORCID \# 0000-00017474-9696

Ruth Wylie (Ph.D.) is the assistant director of the Center for Science and the Imagination and an associate research professor in the Mary Lou Fulton Teachers College at Arizona State University. Ruth earned her PhD in Human-Computer Interaction at Carnegie Mellon University in 2011 and her bachelor's degree at the University of California, Berkeley in Cognitive Science with minors in Computer Science and Education. Ruth concentrates on interdisciplinary, translational research that leverages knowledge and insights from theory and laboratory studies to answer real-world problems. Her previous projects include designing educational technology for students and teachers and developing interdisciplinary collaboration methodologies. ORCID \# 0000-0002-8161-7197 


\section{Appendix A}

\section{Blackfoot Ceremonial Circle}

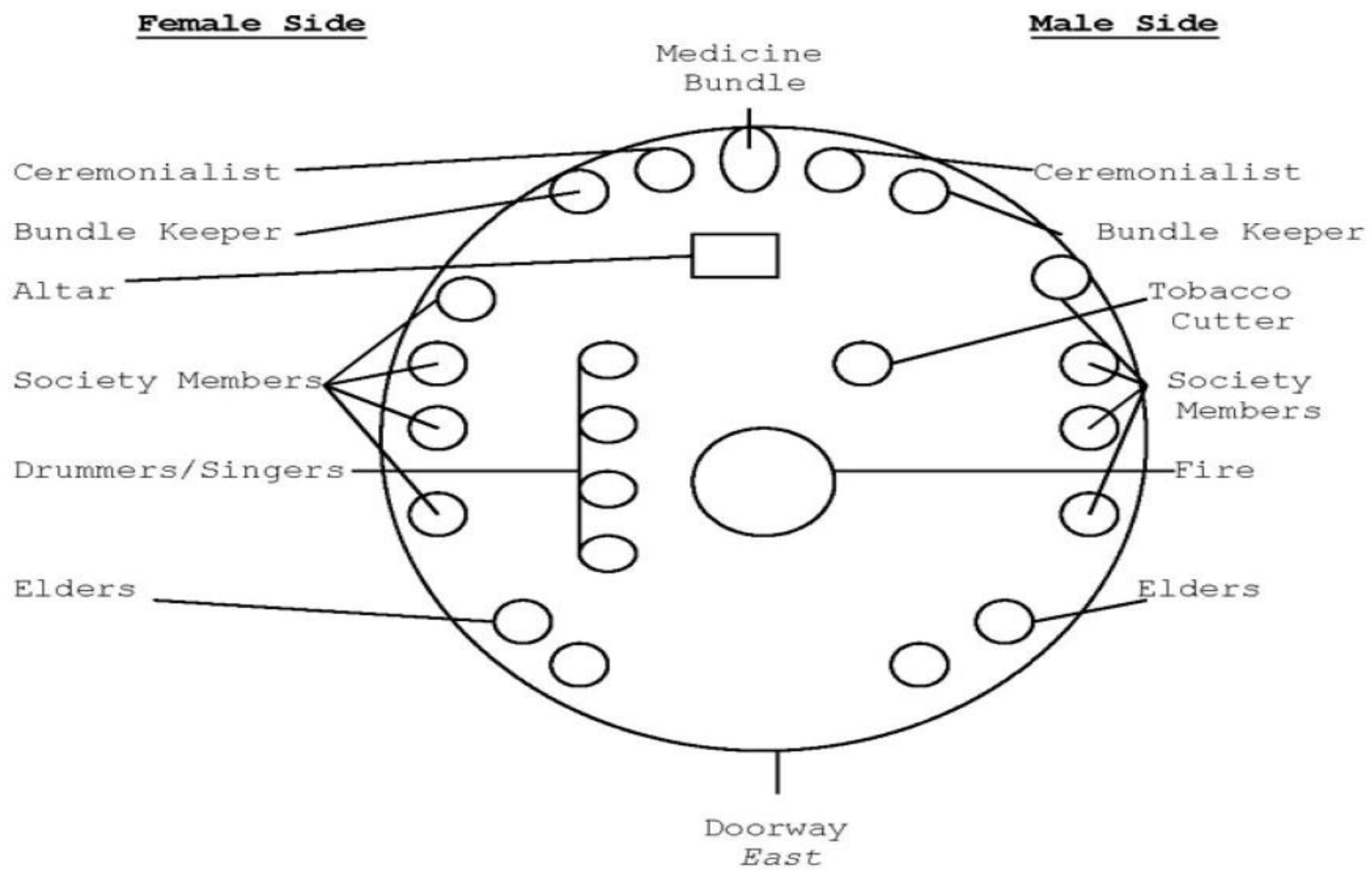

Source: Gladstone \& Pepion, (2016) 
Clark, S.

Appendix B

Voucher of Disinterested Persons/Boarding School Application

Vouchers of Disinterested Persons.

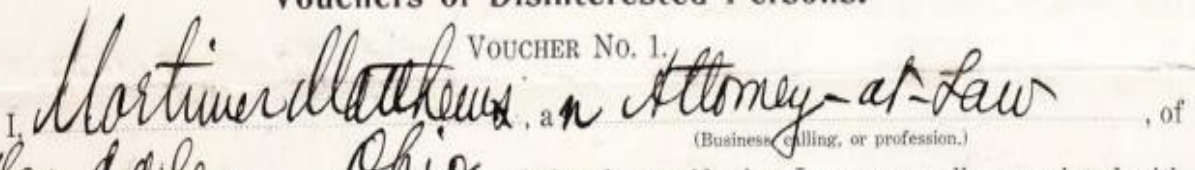

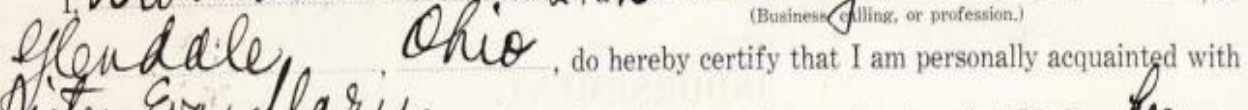

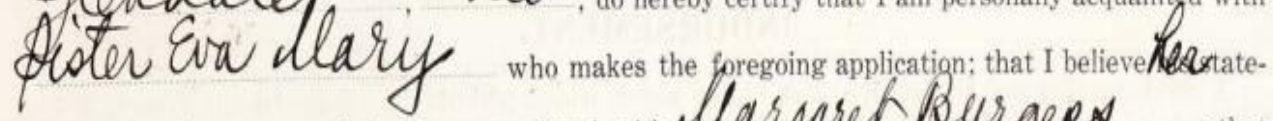
mints therein are true; that I am acquainted with llargare pelergeed ; that 4 he is known and recognized in the community in which $\$$ he lives as an Indian; that in my opinion Q he can not receive proper and adequate schooling at home for the reason that the Condition

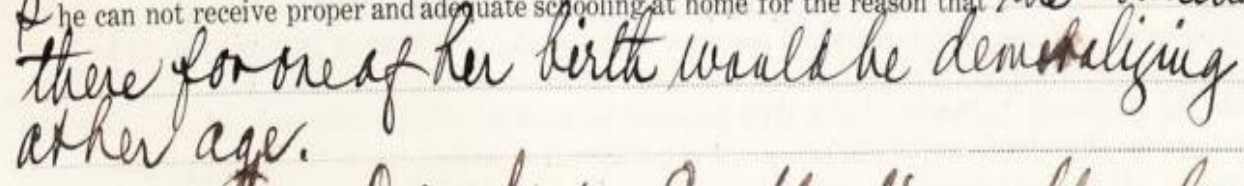

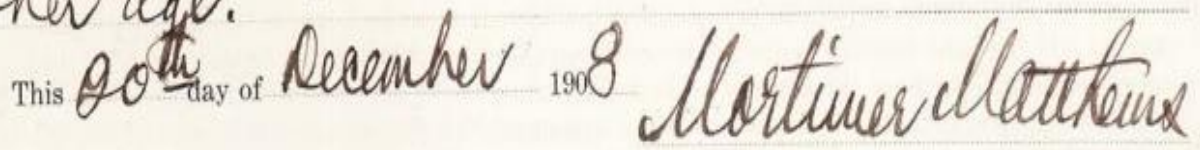

Panel thayhews a Clergyman of

li.

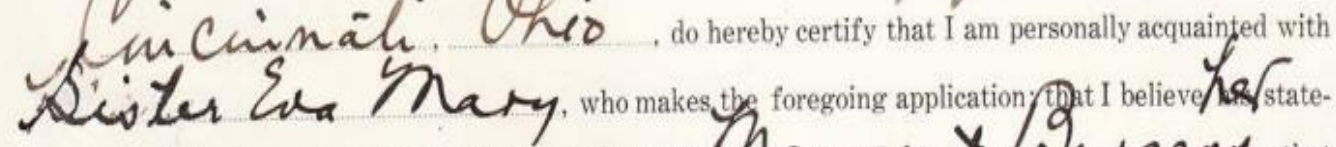
mints therein are true; that I am acquainted with She is known and recognized in the community in which $\int$ he lives as an Indian; and that in my opinion

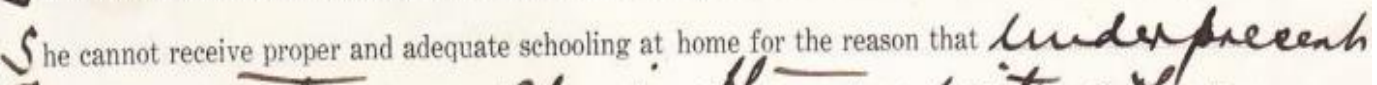
Circumstances the is thrown with other who Can der Res of inferior race s whore

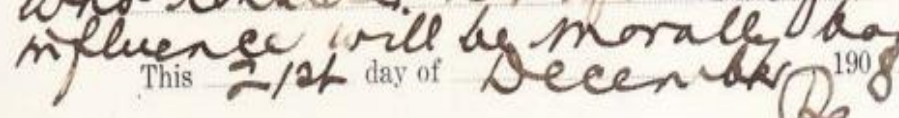

Paul thatheas

345 
Journal of Ethnic and Cultural Studies

\section{Application for Enrollment in a Nonreservation School.}

(For a child not enrolled at an Asency.)

For and in consideration of the United States assuming the care, education, and maintenance in the United States Indian School at Carchic..., of

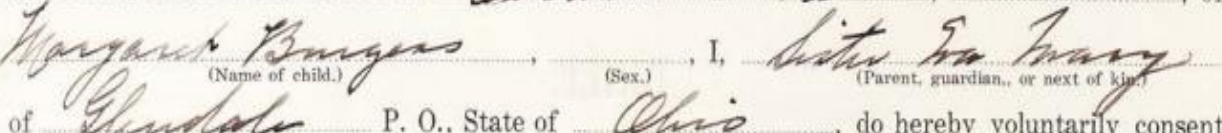
and agree to enrollment in said school for a period of and bind myself to abide by all the rules and regulations for Indian schools.

I further say that the said child was born at.

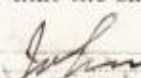

that the fathei,

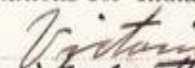
of

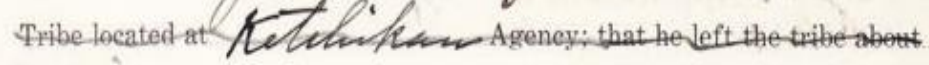

that the mother,
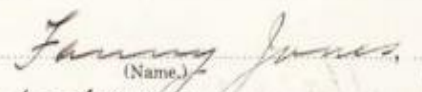

a. Indian of the

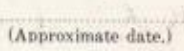

;

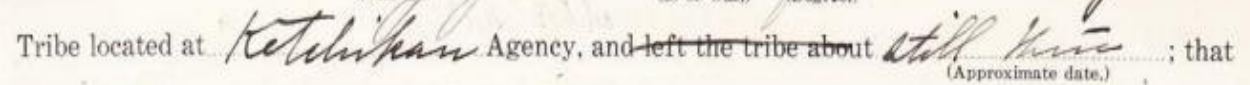
the said child was born and reared in the United States, and now actually resides therein; and that o he has attended the following schools:

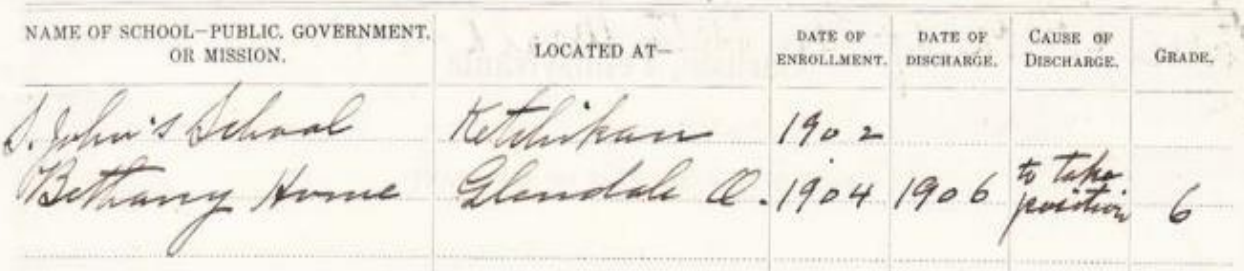

This $1 \%$ day of Dewner, $190 \mathrm{~g}$

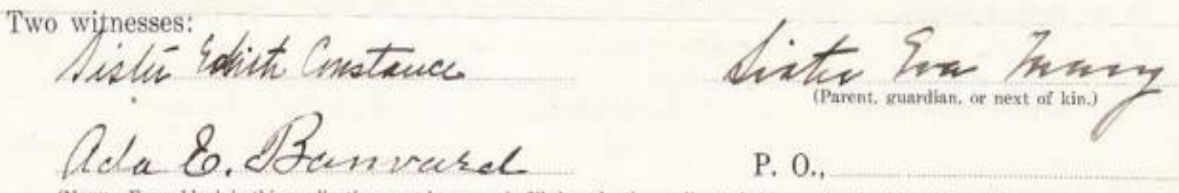

Nork, -Every blank in this application must be properly fllled out by the applieant, in his own handwriting, if possible. The signature, whether by mark or otherwise, must be attested by two witnesser.

\section{AFFIDAVIT.} I. Sistes bra very

, do hereby swear that the statements made in the

Sworn to and subscribed before me this

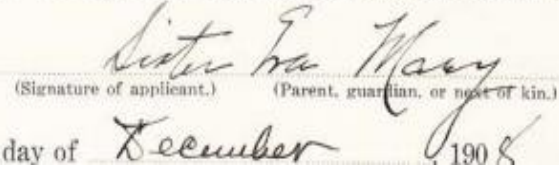

Source: Clark, (2020) 